\title{
Pathogens compromise reproduction and induce melanization in Caribbean sea fans
}

\author{
L. E. Petes ${ }^{1, *}$, C. D. Harvell ${ }^{2}$, E. C. Peters ${ }^{3}$, M. A. H. Webb $^{4}$, K. M. Mullen ${ }^{2}$ \\ ${ }^{1}$ Department of Zoology, Oregon State University, Corvallis, Oregon 97331, USA \\ ${ }^{2}$ Department of Ecology and Evolutionary Biology, Cornell University, Ithaca, New York 14853, USA \\ ${ }^{3}$ Tetra Tech, Fairfax, Virginia 22030, USA \\ ${ }^{4}$ Department of Fisheries and Wildlife, Oregon State University, Corvallis, Oregon 97331, USA
}

\begin{abstract}
The fungal pathogen Aspergillus sydowii is causing high mortality of sea fan gorgonians Gorgonia ventalina in a Caribbean-wide outbreak. Fungal infection induces a localized band of melanin adjacent to fungal hyphae. We also detected an unidentified parasite that induced a similar melanin band, suggesting that melanization is a generalized response to infection. Although a common mechanism of antifungal defense in insects, this is the first report of melanization in a cnidarian. Histological analysis also revealed that sea fans are gonochoric, and reproduction was suppressed in fungus-infected colonies throughout the year. Fans infected with the fungus contained few or no gametes in comparison to fecund healthy fans. Every fan with fungal lesions covering between 10 and $20 \%$ of fan area was reproductively compromised; $64 \%$ of infected fans were reproductively inactive. Since prevalence of infection increases with increasing colony size, compromised reproductive of the largest, most fecund fans will amplify the epizootiological and selective impacts of this outbreak. This new evidence suggesting reproductive suppression in diseased gorgonians indicates that demographic costs may occur for those populations surviving disease outbreaks.
\end{abstract}

KEY WORDS: Gorgonian disease $\cdot$ Compromised reproduction · Melanization · Gorgonia ventalina • Aspergillus sydowii

Resale or republication not permitted without written consent of the publisher

\section{INTRODUCTION}

New disease outbreaks in many taxa of corals are causing high mortality in the Caribbean (Weil \& Smith 2003). Mechanisms of direct resistance to fungal attack and the impact of infection on coral reproduction are still unknown. Suppressed reproduction in survivors of prevalent diseases could have large impacts on population biology, sustainability and evolution. An important component of natural selection, and one less easily measured than mortality selection, is fecundity selection (Endler 1986, Kingsolver et al. 2001). Pathogens that suppress reproduction have a disproportionate effect on the evolution of host characteristics (Endler 1986, Altizer et al. 2003). Pathogens are known to compromise fecundity, or reproductive output, of invertebrates (Burdon \& Müller 1987, Walker et al. 1999, Fleury et al. 2000). Bacterial and viral infec- tions in insects lead to decreased reproductive rates, lower egg production, and shorter lifespan in females (Marina et al. 1999, Fleury et al. 2000). Fungal infection leads to suppressed yield and delayed maturity of cotton plants (Walker et al. 1999). Coral bleaching can lead to an extreme decrease in fecundity of colonies if recovery from the event is slow (Szmant \& Gassman 1990, Michalek-Wagner \& Willis 2001). Yet there is no information on the effects of pathogens on coral reproductive potential.

Sea fans Gorgonia ventalina are abundant in Caribbean reef ecosystems and are important members of reef communities (Opresko 1973, Nagelkerken et al. 1997b). Aspergillus sydowii is a terrestrial fungus newly reported as a pathogen of gorgonians in the oceans (Smith et al. 1996, Kim et al. in press). Signs of aspergillosis infection described in sea fans include tissue thickened with gorgonin (tumors), small $\left(<1 \mathrm{~cm}^{2}\right)$ 
purpled areas of tissue (spots), and areas of necrosis (lesions) surrounded by purple halos (Nagelkerken et al. 1997a, Smith et al. 1996, Kim \& Harvell 2001). 'Purpling' is a generalized response that appears when a sea fan is infected with A. sydowii or experiences stress via abrasion with a biotic agent, such as the fire coral Millepora alcicornis (Alker 2000). Signs of aspergillosis are most common on large sea fans and can lead to mortality of entire colonies (Nagelkerken et al. 1997a, Kim \& Harvell 2001, Jolles et al. 2002). Fans throughout the Caribbean have suffered high mortality and have unusually high prevalence rates; in some locations and times, all large fans exhibit signs of infection (Nagelkerken et al. 1997a, Kim \& Harvell 2001, Jolles et al. 2002).

Gorgonians and scleractinian corals possess several mechanisms to resist infections, but the type of immune response and its success varies with both the taxon and individual colony expression (Harvell et al. in press). Antifungal activity is high in sea fans and other gorgonians (Kim et al. 2000a,b). In sea fans, levels of antifungal activity are highest adjacent to lesions (Kim et al. 2000a), and natural levels suppress growth of Aspergillus sydowii (Dube et al. 2002). Alker (2000) hypothesized that the purple coloration of tissue is related to a melanization response to aspergillosis. In this study, using histological techniques, we examined the mechanism of gorgonian resistance to A. sydowii infection and the impacts of the fungus on reproduction.

\section{MATERIALS AND METHODS}

All tissue samples were collected using SCUBA at Pickles Reef in the Florida Keys, USA, and were immediately fixed in $10 \%$ formalin in seawater and subsequently decalcified for $7 \mathrm{~d}$ in an aqueous solution of sodium citrate and formic acid. Histological samples were embedded in paraffin and sectioned at $4 \mu \mathrm{m}$ (Cornell Veterinary School). To investigate gonad maturity, all sea fans were stained with hematoxylin and eosin (H\&E) according to Preece (1972).

To investigate a possible melanization response, two $3 \mathrm{~cm}^{2}$ samples were collected from diseased fans $(\mathrm{n}=5): 1$ sample of the purpled area adjacent to a lesion and 1 sample of non-purpled tissue $10 \mathrm{~cm}$ away. Control tissue was similarly excised from sea fans with no visible signs of disease $(n=8)$. Staining with $H \& E$ revealed melanin as a distinct yellow band, the width of which was digitally measured using an Olympus microscope at $4 \times$ with a Dage-MTI DC-330 color camera and MetaMorph software (Universal Imaging Corporation). In addition to the H\&E stain, sections from 1 healthy and 1 lesion sample were stained to determine the presence of melanin, using the Fontana-
Masson, periodic acid-Schiff (PAS), melanin bleach, and acid-fast for lipofuchsin procedures. The staining reactions in these sections validated the identification of the melanin band found with the H\&E stain. Grocott's methenamine silver (GMS) procedure was used to verify the presence of fungal hyphae, although the hyphae were readily visible in H\&E-stained sections.

Melanin band-width measurements were made of tissue from healthy fans, healthy (non-purpled) tissue from infected fans, and tissue infected by Aspergillus sydowii or the unidentified parasite. A Student's 2 -sample $t$-test was conducted using S-Plus software, Version 6.1 (Insightful Corporation), and no significant difference was found between the thickness of the melanin layer of tissue from healthy sea fans and uninfected tissue from diseased fans $(p=0.99)$; thus, these 2 categories were pooled and considered to be 'uninfected'. A Student's 2-sample $t$-test was conducted between the pooled 'uninfected' sea fans and sea fans infected with the unidentified parasite and/or fungal hyphae.

Sea fan tissue samples were collected from healthy and diseased sea fans in January, May and October 2001 to examine gonad maturation. Diseased fans were identified by the presence of a purpled lesion. Square pieces $\left(3 \mathrm{~cm}^{2}\right)$ were removed from healthy ( $\mathrm{n}=3$ to 4 ) and diseased ( $\mathrm{n}=3$ to 4$)$ sea fans. In January, 2 pieces were excised from areas in the middle of 4 healthy fans at least $10 \mathrm{~cm}$ apart; 4 diseased colonies were sampled directly adjacent to a lesion, and 1 area was sampled $10 \mathrm{~cm}$ away. In each of the other time periods, 3 pieces were excised from each diseased sea fan along the following gradient: purpled tissue adjacent to lesion (center), mildly purpled tissue $10 \mathrm{~cm}$ away from lesion (middle), and healthy tissue with no obvious purpling $20+\mathrm{cm}$ away from lesion (edge). Samples were excised from corresponding areas of healthy fans at each time period. Histological slides were examined using the $10 \times$ objective of an Olympus BH-2 compound microscope, and the number of oocytes present along $2 \mathrm{~cm}$ axial skeleton strips at the top and bottom of the slide was quantified. Microscopic examination of samples revealed very few males; they were therefore excluded from this study.

Initially, data were analyzed with a repeatedmeasure ANOVA that included terms for season of observation, health status, and site of collection, as well as a term for the repeated measure on the same fan within a season $\times$ health status subclass. In May and October, samples from healthy and diseased fans collected along a gradient within each fan did not differ significantly in the number of oocytes per polyp $(p=0.5775)$; thus, subsequent analyses ignored this effect. Accordingly, the results presented here are based on a repeated-measures analysis with fans nested in a 
season $\times$ health subclass. All computations were performed with the general linear model procedure of the Statistical Analysis System (SAS), Version 8.02.

\section{RESULTS AND DISCUSSION}

Histological examination of lesions revealed necrotic tissue, layering of the axial skeleton, and melanin deposition, whereby the axis was infected with the fungus (Fig. 1a). Melanin was indicated by a black band resulting from the Fontana-Masson staining procedure and was confirmed by staining with a melanin bleach procedure, whereby melanin sites were unstained in the bleached sections and black in the stained sections (not shown). The GMS stain revealed fungal hyphae, and the H\&E counterstain identified melanin as a yellow band (Fig. 1a). H\&E also revealed thick deposits of melanin along areas of the axial skeleton invaded by an unidentified parasite characterized by purple-staining ovoid bodies in a densely-staining blue mucus (Fig. 1b). Similar to fungal hyphae, this parasite was observed invading the gorgonin, and the presence of melanin suggests that this is a generalized response to infection. Healthy sea fans and healthy (non-purpled) tissue from diseased fans had thin or no melanin layers (Fig. 1c). The mean melanin band-width was thicker in areas adjacent to infected axial skeleton $(0.336 \mathrm{~mm})$ than in uninfected tissue $(0.033 \mathrm{~mm}$; Student's $t=7.3894, \mathrm{df}=16, \mathrm{p}<$ 0.0001). Many plants and invertebrates utilize the pigment melanin as a defense against parasites and fungal pathogens (Bell 1981, Golkar et al. 1993). Cuticular melanization in insects can occur as a cell-mediated event in response to tissue injury or microbial invasion (Ashida \& Brey 1995, Taft et al. 2001). Induced melanization and encapsulation in mosquito larvae against fungal pathogens and parasites result in lower larval mortality (Golkar et al. 1993). This study is the first report of melanization in a gorgonin-producing cnidarian.

Gonad tissue was examined to evaluate if the high number of infected sea fans exhibiting melanization were also reproductively compromised. Examination of tissue showed that sea fans are gonochoric; for the purpose of this study, the stage of maturity was only determined in females, since very few of the samples collected were identified as males. Early vitellogenic oocytes were found in October, and mature oocytes were found in May, which is consistent with the summer spawning time of most gorgonians (Brazeau \& Lasker 1989). The reproductive effort of diseased colonies was lower than that of healthy colonies at each sampling period (Fig. 2). In January, healthy fans contained more oocytes per polyp than diseased fans $(p=0.0022)$. In May, spawning had been initiated as indicated by several spawned-out polyps. At this time
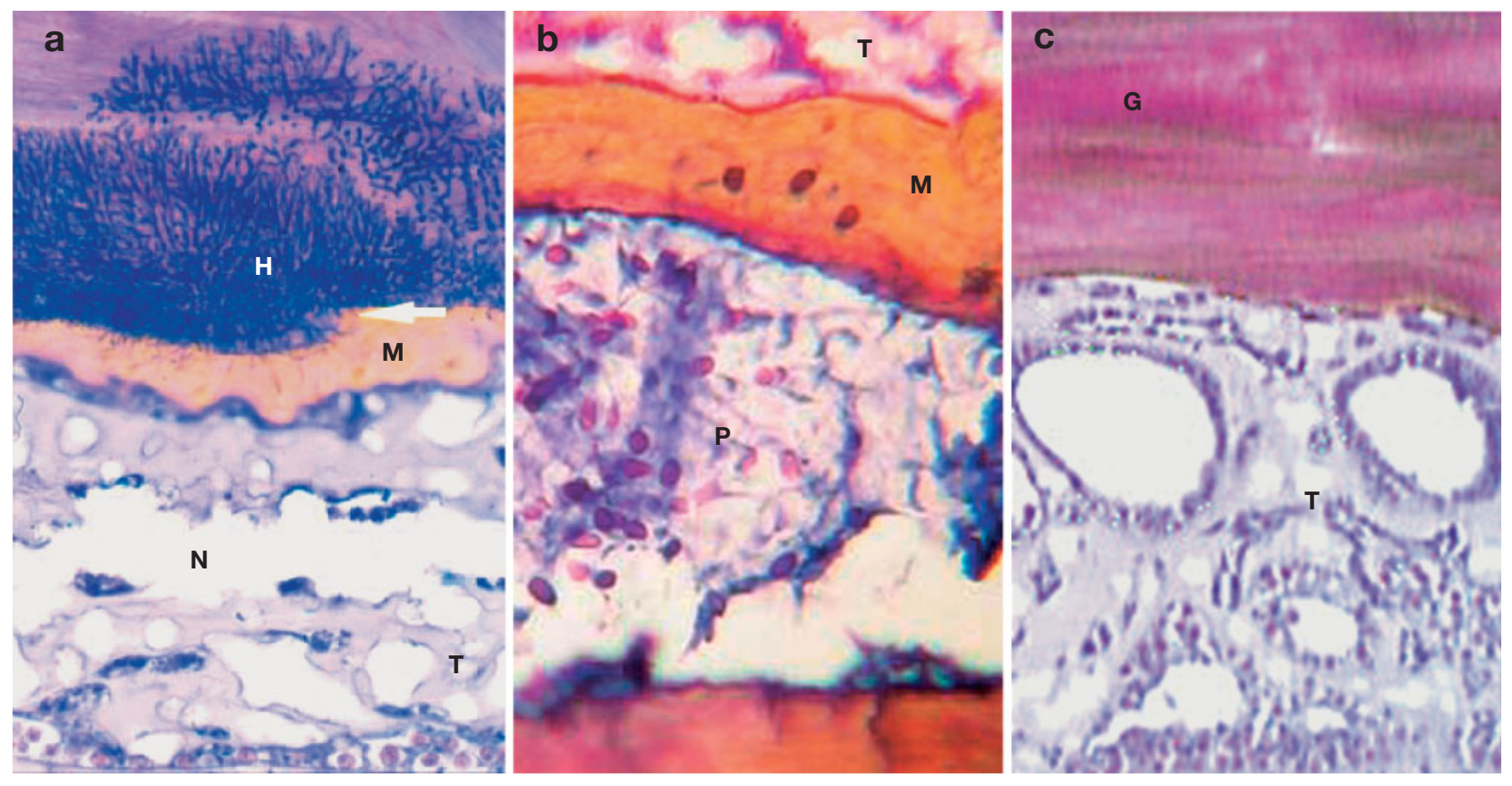

Fig. 1. Gorgonia ventalina infected by Aspergillus sydowii. Light microscopic views of melanization of diseased tissue. (a) Thickening of melanin $(\mathrm{M})$ between area of hyphal invasion $(\mathrm{H})$ of axial skeleton and necrotic tissue $(\mathrm{N})$ adjacent to healthy tissue $(\mathrm{T})$; $(\mathrm{b})$ thick melanin layer surrounding unidentified ovoid parasite (P) and associated blue-stained mucus; (c) healthy sea fan tissue adjacent to uninfected gorgonin skeleton $(\mathrm{G})$. All slides are stained with Hematoxylin \& Eosin (H\&E) 

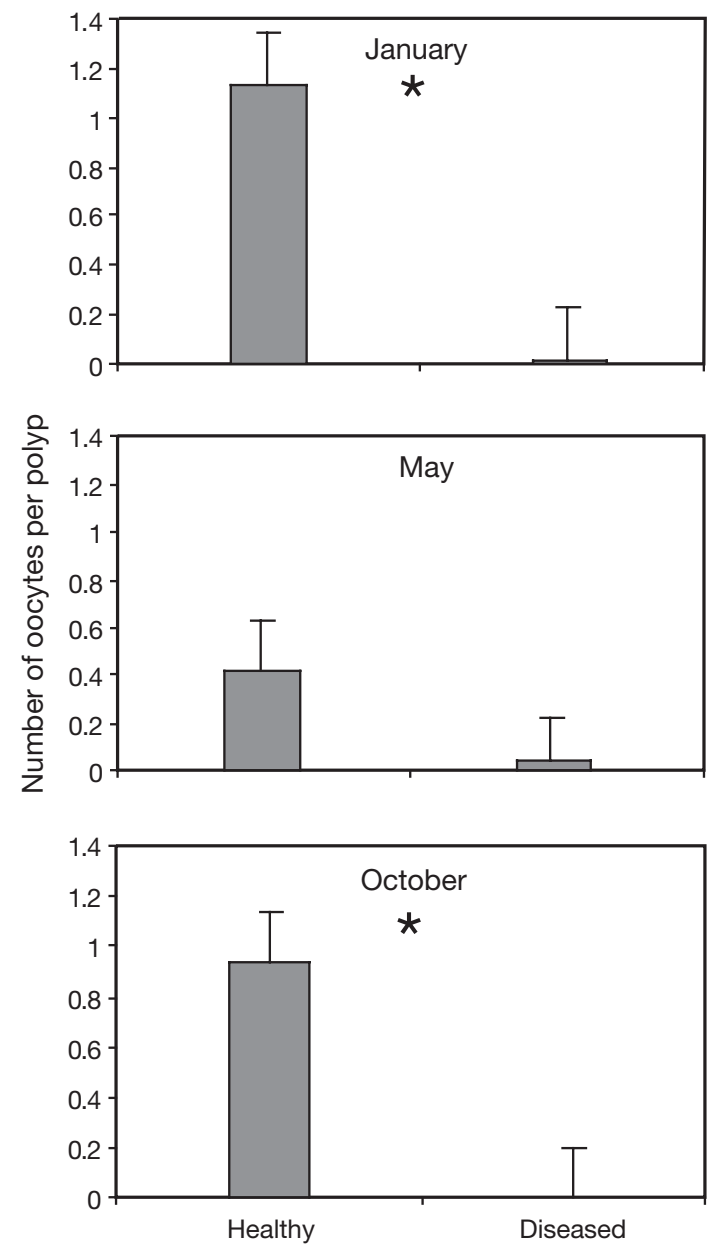

Fig. 2. Gorgonia ventalina infected by Aspergillus sydowii. Total average number of oocytes divided by total number of polyps ( $\mathrm{n}=3$ to 4 healthy and 3 to 4 diseased fans at each sampling time). No oocytes were present in diseased fans in October. Asterisk indicates significant difference between healthy and diseased fans at same sampling time; error bars = 1 SD (ANOVA incorporating fan-to-fan variance) there was no significant difference between the number of oocytes per polyp in healthy and diseased colonies $(p=0.1800)$. Histology indicated the presence of mature oocytes undergoing resorption. Ovarian atresia is known to occur in organisms in response to stress (i.e. Linares-Casevane et al. 2002). Atresia and spawned-out polyps may explain the low number of oocytes per polyp in May in both healthy and diseased fans. Healthy sea fans in October contained developing gametes, whereas samples from diseased colonies contained no oocytes ( $p=0.0049)$.

In fans pooled over all 3 sampling times, only 1 of the 10 healthy fans was non-reproductive (no oocytes present), whereas 7 of the 11 diseased fans were nonreproductive $\left(\chi^{2}=6.391 ; \mathrm{p}=0.0115\right.$; see Fig. 3 for images of healthy and diseased tissue). It is not known why 1 healthy fan was reproductively inactive, but since this is the first study of reproduction in Gorgonia ventalina, further work needs to be conducted to determine the reproductive cycle of this species. Analysis of the ratio of non-reproductive polyps to total polyps revealed that diseased fans have a higher proportion of non-reproductive polyps than healthy fans. In January, $98 \%$ of polyps were non-reproductive in diseased fans, whereas only $36 \%$ of polyps in healthy fans contained no oocytes (ANOVA, p = 0.0026). Diseased colonies sampled in May had $96 \%$ non-reproductive polyps; in healthy colonies, $62 \%$ of polyps were non-reproductive $(p=0.0420)$. Diseased sea fan samples in October exhibited total reproductive suppression, as $100 \%$ of polyps scored were nonreproductive, while $41 \%$ of healthy fan samples (from this month) were non-reproductive ( $p=0.0025)$. This indicates localized suppression of reproduction and also suggests a more systemic effect, as even those samples collected furthest away from a lesion were non-reproductive.
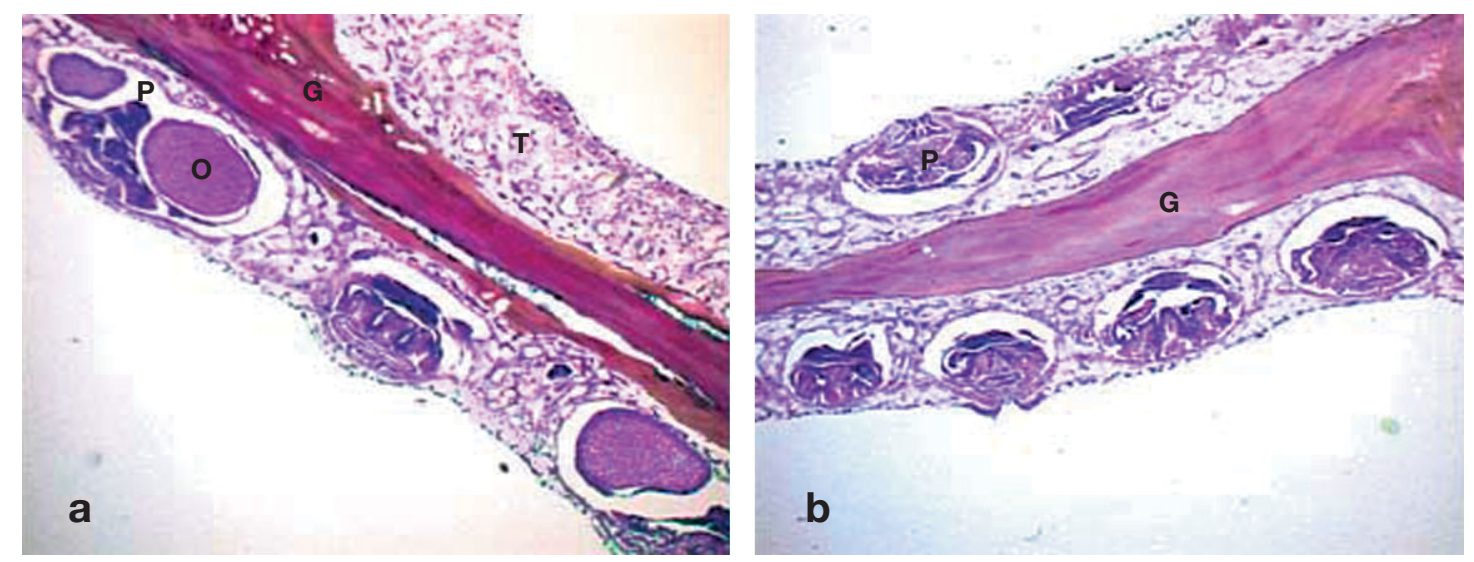

Fig. 3. Gorgonia ventalina. Histological slides. (a) Mature, vitellogenic oocytes (O) developing within polyps (P), which comprise feeding structures in tissue $(\mathrm{T})$ surrounding the gorgonin $(\mathrm{G})$ in a non-aspergillotic sea fan; (b) tissue with no oocytes in a fan exhibiting visible signs of aspergillosis 
The prevalence and severity of aspergillosis is much greater in larger sea fans (Nagelkerken et al. 1997b, Kim \& Harvell 2001, Dube et al. 2002, Jolles et al. 2002). At some sites in the Florida Keys, $>90 \%$ of the largest fans are infected (Kim \& Harvell 2001, Jolles et al. 2002). Since reproductive tissue area increases with increasing fan size, large sea fans will inevitably contribute more gametes to the reproductive pool in a healthy population. High prevalence of aspergillosis and resulting compromised reproduction in large fans could lead to a decreased number of juvenile sea fans on coral reefs in the future. It is possible that decreased reproduction is caused by pathogens and is also a cost of host defense. Reproductive suppression of sea fans is sufficiently large to affect the population biology of sea fans in the Caribbean and the evolution of gorgonian traits, if suppression is related to phenotype. This is the first study identifying localized resistance and reproductive suppression in diseased gorgonians.

Acknowledgements. Comments and suggestions from J. R. Ward, K. L Rypien, and J. F. Bruno are greatly appreciated. Thanks to T. Famula at the University of California, Davis, for statistical advice, M. Nardi at the Cornell Biomedical Science laboratory for histological preparation, and C. Bayles at the Microscopy and Imaging Facility in the Cornell Biotechnology Resource Center, for imaging assistance. Funding was provided by the NSF REU program, the Howard Hughes fellowship for undergraduates, and the Cornell Biology Honors program.

\section{LITERATURE CITED}

Alker AP (2000) Localized induction of a multivariate structural response in sea fans to predators, competitors, and pathogens. MS thesis, Cornell University, Ithaca, NY

Altizer S, Harvell CD, Friedle E (2003) Rapid evolutionary dynamics and disease threats to biodiversity. Trends Ecol Evol 18:589-596

Ashida M, Brey PT (1995) Role of the integument in insect defense: pro-phenol oxidase cascade in the cuticular matrix. Proc Natl Acad Sci USA 92:10 698-10 702

Bell AA (1981) Biochemical mechanisms of disease resistance. Annu Rev Plant Physiol Plant Mol Biol 32:21-81

Brazeau DA, Lasker HR (1989) The reproductive cycle and spawning in a Caribbean gorgonian. Biol Bull (Woods Hole) 176:1-7

Burdon JJ, Müller WJ (1987) Measuring the cost of resistance to Puccinia coronata Cda in Avena fatua L. J Appl Ecol 24:191-200

Dube D, Alker AP, Kim K, Harvell CD (2002) Size structure and geographic variation in chemical resistance of sea fan corals (Gorgonia ventalina) to a fungal pathogen. Mar Ecol Prog Ser 231:139-150

Endler JA (1986) Natural selection in the wild. Princeton University Press, Princeton

Fleury F, Vavre F, Ris N, Fouillet P, Boulétreau M (2000) Physiological cost induced by the maternally-transmitted endosymbiont Wolbachia in the Drosophila parasitoid Leptopilina heterotoma. Parasitology 121:493-500

Golkar L, LeBrun RA, Ohayon H, Gounon P, Papierok B, Brey PT
(1993) Variation of larval susceptibility to Lagenidium giganteum in three mosquito species. J Invertebr Pathol 62:1-8

Harvell CD, Mullen KM, Peters EC (in press) Coral resistance to disease. In: Rosenberg E, Loya Y (eds) Coral health and disease. Springer-Verlag, Heidelberg

Jolles A, Sullivan P, Alker AP, Harvell CD (2002) Disease transmission of aspergillosis in sea fans: inferring process from spatial pattern. Ecology 83:2373-2378

Kim K, Harvell CD (2001) Aspergillosis of sea fan corals: disease dynamics in the Florida Keys. In: Porter JW, Porter KG (eds) The Everglades, Florida Bay, and coral reefs of the Florida Keys: an ecosystem sourcebook. CRC Press, New York, p 813-824

Kim K, Harvell CD, Kim PD, Smith GW, Merkel SM (2000a) Fungal disease resistance of Caribbean sea fan corals (Gorgonia spp.). Mar Biol 136:259-267

Kim K, Kim PD, Alker AP, Harvell CD (2000b) Chemical resistance of gorgonian corals against fungal infections. Mar Biol 137:393-401

Kim K, Dobson A, Gulland FM, Harvell CD (in press) Disease and the conservation of marine diversity. In: Norse E, Crowder L (eds) Conservation of marine ecosystems. Island Press, Washington, DC

Kingsolver JG, Hoekstra HE, Hoekstra JM, Berrigan D and 5 others (2001) The strength of phenotypic selection in natural populations. Am Nat 157:245-261

Linares-Casevane J, Van Eenennaam JP, Doroshov SI (2002) Ultrastructural and histological observations on temperature-induced follicular ovarian atresia in the white sturgeon. J Appl Ichthyol 18:382-390

Marina CF, Arredondo-Jiménez JI, Castillo A, Williams T (1999) Sublethal effects of iridovirus disease in a mosquito. Oecologia 119:383-388

Michalek-Wagner K, Willis BL (2001) Impacts of bleaching on the soft coral Lobophytum compactum. I. Fecundity, fertilization and offspring viability. Coral Reefs 19:231-239

Nagelkerken I, Buchan K, Smith GW, Bonair K and 8 others (1997a) Widespread disease in Caribbean sea fans: I. Spreading and general characteristics. Proc 8th Int Coral Reef Symp 1:679-682

Nagelkerken I, Buchan K, Smith G, Bonari K and 10 others (1997b) Widespread disease in Caribbean sea fans: II. Patterns of infection and tissue loss. Mar Ecol Prog Ser 160:255-263

Opresko DM (1973) Abundance and distribution of shallowwater gorgonians in the area of Miami, Florida. Bull Mar Sci 23:535-558

Preece A (1972) A manual for histologic technicians, 3rd edn. Little, Brown \& Co, Boston, MA

Smith GW, Ives LD, Nagelkerken I, Ritchie KB (1996) Caribbean sea fan mortalities. Nature 383:487

Szmant AM, Gassman NJ (1990) The effects of prolonged 'bleaching' on the tissue biomass and reproduction of the reef coral Montastrea annularis. Coral Reefs 8:217-224

Taft AS, Chen CC, Li J, Christensen BM (2001) Molecular cloning of two prophenoloxidase genes from the mosquito Aedes aegypti. Insect Mol Biol 10:97-103

Walker NR, Kirkpatrick TL, Rothrock CS (1999) Effect of temperature on and histopathology of the interaction between Meloidogyne incognita and Thielaviopsis basicola on cotton. Phytopathology 89:613-617

Weil E, Smith G (2003) Scleractinian and octocoral disease Caribbean-wide. In: Kasim Moosa MK, Soemodihardjo S, Nontji A, Soegiarto A, Romimohtarto K, Sukarno, Suharsono (eds) Proceedings of the Ninth International Coral Reef Symposium, Bali, Indonesia, October 23-27, 2000. Indonesian Institute of Sciences 